\title{
CONCEPT OF LOGISTICS PREVENTION DEVELOPMENT IN A DEFENCE SYSTEM
}

\author{
Igor J. Epler ${ }^{a}$, Marko D. Andrejić ${ }^{b}$, Marjan A. Milenkov ${ }^{c}$, \\ Vlada S. Sokolovićd \\ University of Defence in Belgrade, Military Academy, \\ Department of Logistics, Belgrade, Republic of Serbia \\ a e-mail: igorepler@gmail.com, \\ ORCID iD: - http://orcid.org/0000-0002-1616-5139 \\ b e-mail: markoandrejic@hotmail.com, \\ ORCID iD: (Dhttp://orcid.org/0000-0002-6753-9786, \\ c e-mail: marjan.milenkov@va.mod.gov.rs, \\ ORCID iD: (i)http://orcid.org/0000-0003-2054-0525, \\ de-mail: vlada.sokolovic@va.mod.gov.rs, \\ ORCID iD: (Dhttp://orcid.org/0000-0003-0782-0506
}

http://dx.doi.org/10.5937/vojtehg65-8884

FIELD: Logistics (organisation, economy, logistics management)

ARTICLE TYPE: Professional Paper

ARTICLE LANGUAGE: English

Abstract:

Logistics prevention should be viewed as a system (composed of subsystems and components), as a function (group of related tasks grouped according to certain criteria) and as a process (course of arranged events in time). Logistics prevention is a part of the overall defence system logistics suport which prevents the infringe of projected and present performances of a supported system. Logistics prevention, as a function, includes all measures and activities planned by logistics authorities and implemented by logistics authorities and non logistics personnel. They are aimed at preventing the occurence of phenomena and processes that negatively affect the ability and performances of a defence system. At a time of intense defence system organisational changes, the approach to logistics prevention should be systematic and adequately dealt with due to its significance. The principles related to design, preparation and operation of the whole defence logistics also relate to design, preparation and implementation of logistics preventive.

Key words: military logistics, system, logistics prevention. 


\section{Introduction}

If a defence system is to perform assigned tasks successfully, achieve results and high set goals and fulfill assigned missions, it is essential to have high-quality logistics support, an important segment of which are logistics prevention activities within all functions of logistics support. Logistics prevention implies a set of measures and procedures planned and organised by logistics administrative authorities, and realised by logistics units and nonlogistics personnel in the defense system, or, if necessary, appropriate entities outside the defense system. Preventive measures and procedures of logistics administrative and executive bodies are focused on preventing the occurrence of adverse events and processes that can act negatively on the ability of the defense system as a complex organisational and multilevel organisational system, in order to reduce the consequences of such events and processes. Prevention in the context of this work involves a holistic approach. It consists of prevention activities carried out by holders of logistics support (LoS) functions (health care, infrastructure, maintenance, supply, transportation, general logistics), prevention activities in the framework of joint LoS functions (planning, purchasing, sales, handling and disposal of material assets, payment services to third parties, etc.), and prevention of logistics character in the preparation and use of supported systems (preparation, equipment based on merit, development, use). Only in this way it is possible to approach prevention globally and act locally, ensuring maximum defense system readiness with optimised costs.

Logistics prevention has been treated differently by bearers of logistics functions. Therefore, achievements are different in each of the logistics functions. There was no common wiev on logistics prevention management among logistics functions as shown below in Table 1.

\section{Examples of logistics preventive application in practice}

There are many examples of intensifyng measures and procedures when logistics-related objects face some kind of unwanted state (Atanasković et al, 2012a, pp.191-199), (Atanasković et al, 2012b, pp.69-78).

In such situations, the organisation system performaces become vulnerable. In all logistics functions, there are many examples of implementing prevention activities since they have numerous benefits, some of which are shown further on in the paper. 
Table 1 - Review of prevention activities related to logistics functions

Таблица 1 - Обзор развития профилактических мероприятий

по функциям логистики

Табела 1 - Преглед развоја превентивних активности по функцијама логистике

\begin{tabular}{|c|c|c|}
\hline SUPPLY & MAINTENANCE & COMMISSARIAT \\
\hline 1 & 2 & 3 \\
\hline $\begin{array}{l}\text { I LEVEL (batallion) } \\
\text { - requisition, } \\
\text { - warehousing, } \\
\text { - guarding, } \\
\text { - proposal of a renewal plan, } \\
\text { - dispersion of material } \\
\text { reserves, } \\
\text { - professional soldier } \\
\text { training. }\end{array}$ & $\begin{array}{l}\text { I LEVEL (batallion) } \\
\text { - basic maintenance, } \\
\text { - technical maintenance } \\
\text { (I, II technical inspection), } \\
\text { - professional soldier training. }\end{array}$ & $\begin{array}{l}\text { I LEVEL (batallion) } \\
\text { - feeding, } \\
\text { - water supply, } \\
\text { - dressing, } \\
\text { - bathing, } \\
\text { - haircutting, } \\
\text { - periodical inspection of } \\
\text { equipment, } \\
\text { - professional soldier } \\
\text { training. }\end{array}$ \\
\hline $\begin{array}{l}\text { II LEVEL (brigade) } \\
\text { - procurement for stock } \\
\text { management, } \\
\text { - budget and echelonment, } \\
\text { - warehousing, } \\
\text { - guarding, } \\
\text { - stock renewal, } \\
\text { - dispersion of material } \\
\text { reserves, } \\
\text { - professional soldier } \\
\text { training. }\end{array}$ & $\begin{array}{l}\text { II LEVEL (brigade) } \\
\text { - basic maintenance, } \\
\text { - technical maintenance } \\
\text { (I, II technical inspection), } \\
\text { - assistance to the lower } \\
\text { maintenance level, } \\
\text { - professional soldier training. }\end{array}$ & $\begin{array}{l}\text { II LEVEL (brigade) } \\
\text { - disposal, } \\
\text { - professional soldier } \\
\text { training. }\end{array}$ \\
\hline $\begin{array}{l}\text { III LEVEL } \\
\text { (operation unit level) } \\
\text { - procurement for stock } \\
\text { management, } \\
\text { - warehousing, } \\
\text { - guarding, } \\
\text { - stock renewal, } \\
\text { - dispersion of material } \\
\text { reserves, } \\
\text { - professional soldier } \\
\text { training. }\end{array}$ & $\frac{\text { III LEVEL }}{\frac{\text { (operation unit level) }}{\text { - professional soldier training. }}}$ & $\begin{array}{l}\text { III LEVEL } \\
\frac{\text { (operation unit level) }}{\text { - disposal, }} \\
\text { - professional soldier } \\
\text { training. }\end{array}$ \\
\hline $\begin{array}{l}\text { IV LEVEL } \\
\text { (Headquarters level) } \\
\text { - procurement for stock } \\
\text { management, } \\
\text { - warehousing, } \\
\text { - guarding, } \\
\text { - stock renewal, } \\
\text { - dispersion of material } \\
\text { reserves, } \\
\text { - reserves maneuver } \\
\text { - professional soldier } \\
\text { training. }\end{array}$ & $\begin{array}{l}\frac{\text { IV LEVEL }}{\text { (Headquarters level) }} \\
\text { - professional soldier training. }\end{array}$ & $\begin{array}{l}\frac{\text { IV LEVEL }}{\text { (Headquarters level) }} \\
\text { - disposal, } \\
\text { - professional soldier } \\
\text { training. }\end{array}$ \\
\hline
\end{tabular}




\begin{tabular}{|c|c|c|}
\hline TRANSPORT & INFRASTRUCTURE & HEALTH CARE \\
\hline 4 & 5 & 6 \\
\hline $\begin{array}{l}\frac{\text { ILEVEL }}{\text { (batallion) }} \\
- \text { making requirements for } \\
\text { transportation, } \\
\text { - professional soldier training. }\end{array}$ & $\begin{array}{l}\frac{\text { I LEVEL }}{\text { (batallion) }} \\
\text {-regular maintenance of facilities }\end{array}$ & $\begin{array}{l}\frac{\text { I LEVEL }}{\text { (batallion) }} \\
\text { - medical inspection, } \\
\text { - triage, } \\
\text { - water control, } \\
\text { - request for deration, } \\
\text { desinfection and } \\
\text { disinsection, } \\
\text { - professional soldier } \\
\text { training. }\end{array}$ \\
\hline $\begin{array}{l}\frac{\| \text { II LEVEL }}{(\text { brigade) }} \\
\text { - making transportation plans, } \\
\text { - making march plans } \\
\text { - professional soldier } \\
\text { training, } \\
\text { - assistance to lower units, } \\
\text { - professional soldier }\end{array}$ & $\begin{array}{l}\frac{\| \text { LEVEL }}{\text { (brigade) }} \\
- \text { making inspection and } \\
\text { verification plans (lightning } \\
\text { conductors, measuring } \\
\text { equipment, etc.). }\end{array}$ & $\begin{array}{l}\frac{\text { II LEVEL }}{\text { (brigade) }} \\
\text { - assistance to the lower } \\
\text { health care level, } \\
\text { - sending requests for } \\
\text { deration, desinfection } \\
\text { and disinsection, } \\
\text { - professional soldier }\end{array}$ \\
\hline $\begin{array}{l}\text { III LEVEL } \\
\text { (operation unit level) } \\
\text { - making transportation plans, } \\
\text { - making march plans, } \\
\text { - I and II level motion } \\
\text { control, } \\
\text { - professional soldier training. }\end{array}$ & $\begin{array}{l}\text { III LEVEL } \\
\text { (operation unit level) } \\
\text { - forwarding inspection and } \\
\text { verification plans (lightning } \\
\text { conductors, measuring } \\
\text { equipment, etc.) to the fourth } \\
\text { level. }\end{array}$ & $\begin{array}{l}\text { III LEVEL } \\
\text { (operation unit level) } \\
\text { - systematic inspection of } \\
\text { peoples and animals, } \\
\text { - preventive medical } \\
\text { labaratory analysis, } \\
\text { - deration, desinfection } \\
\text { and disinsection, } \\
\text { - professional soldier } \\
\text { training. }\end{array}$ \\
\hline $\begin{array}{l}\text { IV LEVEL } \\
\text { (Headquarters level) } \\
\text { - approvaling of petrol } \\
\text { consumtion quotas, } \\
\text { - main motion control. }\end{array}$ & $\begin{array}{l}\text { IV LEVEL } \\
\text { (Headquarters level) } \\
\text { - approval of inspection and } \\
\text { verification plans (lightning } \\
\text { conductors, measuring } \\
\text { equipment, etc.) and } \\
\text { controlling their realisation }\end{array}$ & $\begin{array}{l}\text { IV LEVEL } \\
\text { (Headquarters level) } \\
- \text { professional soldier } \\
\text { training. }\end{array}$ \\
\hline $\begin{array}{l}\text { The result of friction a } \\
\text { According to (http://www } \\
\text { and corrosion cause redu } \\
\text { in the case of Federal Re } \\
\text { with finding solutions for lo } \\
\text { If tribology knowled } \\
\text { saving is possible. Savin } \\
\text { - reducing energy } \\
\text { - reducing costs o } \\
\text { - reducing mainter } \\
\text { - fewer losses cau } \\
\text { - increasing equip }\end{array}$ & $\begin{array}{l}\text { nd corrosion processes is } \\
\text { narco.rs/o-podmazivanju.ht } \\
\text { tion of GDP for } 4.5 \% \text {. This } \\
\text { ublic of Germany (mostly ir } \\
\text { sses caused by friction, wea } \\
\text { e is applied in all phases } \\
\text { is manifested through ( } F \\
\text { spending due to friction re } \\
\text { lubricants; } \\
\text { ance costs; } \\
\text { sed by failures; } \\
\text { nent efficiency and work }\end{array}$ & $\begin{array}{l}\text { ar and tear of materials. } \\
\text { /, 2015), friction, wear } \\
\text { imount is } 3.5 \text { mil. euros } \\
\text { energy). Tribology deals } \\
\text { and corrosion. } \\
\text { f industrial processes, } \\
\text { ure 1): } \\
\text { ucing; }\end{array}$ \\
\hline
\end{tabular}




\section{Statistics of bearing failures causes}

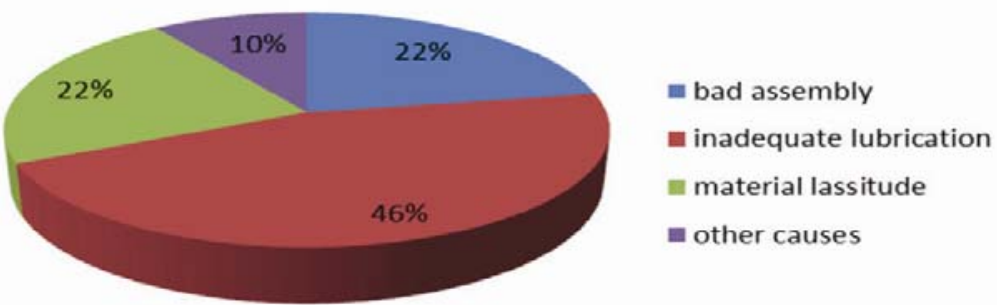

Figure 1 - Statistics of possible causes of bearing failures (http://www.harco.rs/o-podmazivanju.ht/m, 2015)

Puc. 1 - Пример причины отказа подшипников (http://www.harco.rs/o-podmazivanju.htlm, 2015)

Слика 1 - Пример узрока отказивања лежајева (http://www.harco.rs/o-podmazivanju.ht/m, 2015)

Motor vehicles are machines exposed to wear and tear. Today's motor vehicles are sofisticated computer-controlled machines which need less care by consumers and have higher levels of reliability than their precursors. Regular periodical maintenance is important for reliable performances and saving on the road. Because of that, most of big companies sign maintenance contracts in the same time when purchasing new motor vehicles (http://autobusi.net, 2015).

A large number of failures, especially in industries, lead to enormous costs. Saving is significant due to the implementation of infra red thermography (IRT) (http://www.termografija.rs, 2015). Today, IRT is implemented in all areas of the human life (medicine, crime investigation, biology, mechanical engineering, everyday life). Infra red thermography is very important for technical systems diagnostics as a method which does not require halting working processes. Furthermore, IRT can be used for diagnostics of the state of the following equipment:

- electricity and power supply equipment;

- mechanical equipment;

- building constructions;

- industry machines;

- transport infrastructure.

Infra red thermography can discover potential damage on buildings (Figure 2), and enable repair at favorable moments for consumers. In that manner, large scale damage can be avoided. 


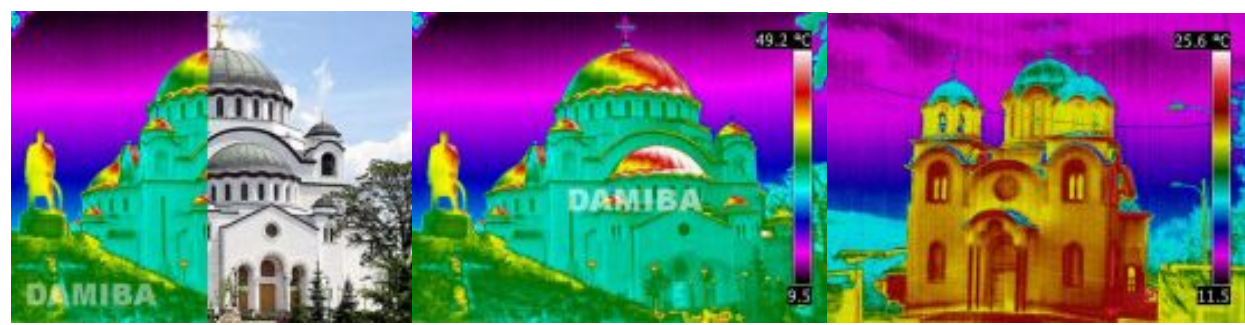

Figure 2 - Thermal images of the Saint Sava's Temple in Belgrade and a Boleč Church (suburb of Belgrade) (http://www.termografija.rs, 2015)

Puc. 2 - Тепловое изображение Храма Святого Саввы и церкви в п. Болеч (http://www.termografija.rs, 2015)

Слика 2 - Термовизијска слика Храма Светог Саве и иркве у Болечу (http://www.termografija.rs, 2015)

Everyday life and powers of the nature point to the necessity to implement logistics prevention (http://studiob.rs, 2015): "Frequent floods on the left Danube river bank are a consequence of uncleaned canals (Figure 3). In order to prevent this, their cleaning has began (http://studiob.rs, 2015)."

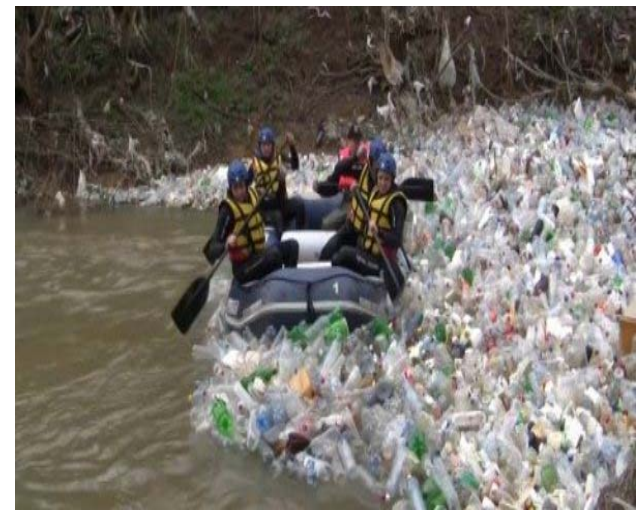

Figure 3- Human carelessness and neglect of nature (http://studiob.rs, 2015)

Puc. 3 - Небрежное и безответственное отношение человека к природе (http://studiob.rs, 2015)

Слика 3 - Људска небрига и немар према природи (http://studiob.rs, 2015)

Preventive reactions are also very important in the logistics field of health care. Regular preventive inspection enables detecting diseases in their initial phase and gives greater chances for full and permanent recovery. Inadequate preparation of medical staff and a lack of complete information about the injured could have unforeseeable consequences, as confirmed by the death toll after the Russian special forces action in the Dubrovka Theater in 2002. 
Given the fact that a human life is priceless, we can emphasise that safety and health at work represent a group of activities which, besides having a human character, contributes significantly to material saving.

The improvement of the present state of defence logistics, as described in this paper, is reflected in the fact that military logistics and its prevention activities should function in accordance with the systematic approach to the management principles and logic of large organisation systems, taking into account particularities of individual logistics functional areas, time requirements and achievements in domestic and world practice as stated above.

The main aim of logistics prevention implementation is to recognize and preemt user requirements.

\section{Development of the logistics prevention concept}

Logistics prevention contributes to raising the level of awareness of logistics service users and contributes to creating conditions for less logistics resources involvement. In that manner, the whole logistics support of the defence system becomes cheaper.

The concept of development of logistics prevention is influenced by the present state of logistics services and numerous factors such as:

- physionomy of contemporary challenges, risks and threats;

- legal and system documents in the defence field;

- structure and size of the army, its organisation and functioning mode;

- achieved level of development of weapons and military equipment;

- achieved level of development of the logistics infrastructure and task execution technology in logistics functions;

- level of logistics culture in the defence system;

- characteristics of logistics requests;

- defence policy.

Logistics prevention should be constantly adjusted to supported system requests; on the other hand, supported systems must be designed taking into account logistics prevention requests. Supported systems also need to adapt to the possibilities of logistics systems (Atanasković et al, 2009, pp.127-139), (Pamučar et al, 2016).

The principles related to design, preparation and functioning of defence logistics also relate to design, preparation and functioning of logistics prevention.

Certain elements of logistics prevention are already built in the defence logistics system in order to perform its tasks shown below in Table 2. 
Table 2-Logistics prevention elements implemented in the system of logistics support design process

Таблица 2 - Элементы профилактических мероприятий, которые необходимо ввести в систему логистической поддержки при проектировании

Табела 2 - Елементи логистичке превентиве које треба уградити при пројектовању система логистичке подршке

\begin{tabular}{|c|c|}
\hline $\begin{array}{l}\text { NAME OF } \\
\text { LOGISTICS } \\
\text { FUNCTION }\end{array}$ & $\begin{array}{c}\text { ELEMENTS OF LOGISTICS } \\
\text { PREVENTION }\end{array}$ \\
\hline ACQUISITION & $\begin{array}{l}\text { Logistics prevention is implemented in the aquistion process by } \\
\text { regulating this area by means of laws, standards and principles, } \\
\text { by creating favorable organisational culture, by defining the } \\
\text { organisation and technology for which it is implemented and by } \\
\text { ensuring transparency in procurement. } \\
\text { The quality of the ordered products and services is controlled by the } \\
\text { purchaser. }\end{array}$ \\
\hline SALE & $\begin{array}{l}\text { Logistics prevention is implemented in the sale process by } \\
\text { regulating this area by means of laws, standards and principles, by } \\
\text { creating favorable organisational culture, by defining the } \\
\text { organisation and technology for which it is implemented and by } \\
\text { ensuring transparency in sale. }\end{array}$ \\
\hline SUPPLY & $\begin{array}{l}\text { The correct expression of the need for equipment; establishing the } \\
\text { standards, criteria and norms for rations; research of the market and } \\
\text { supply sources; defining the focus and priorities, monitoring, } \\
\text { inventory management of stored materials. }\end{array}$ \\
\hline & $\begin{array}{l}\text { Application of maintenance systems for all classes of equpment, taking } \\
\text { into account their particularities } \\
\text { Basic maintenance (daily inspections, periodic inspections, operation, } \\
\text { exploitation measurements); } \\
\text { Technical maintenance (the first inspection and the second inspection, } \\
\text { inspection of less complex equipment, conservation, maintenance } \\
\text { assistance in the performance of basic periodic inspections); }\end{array}$ \\
\hline MAINTENANCE & $\begin{array}{l}\text { Medium repair (medium repair of components and aggregates taking into } \\
\text { consideration time and exploitation resources, conservation, assistance to } \\
\text { maintenance technical inspections); } \\
\text { General overhaul (general overhaul of components and aggregates taking } \\
\text { into consideration time and exploitation resources, conservation, } \\
\text { assistance to medium repair; } \\
\text { Revision (equipment, components and aggregates); } \\
\text { Checks Inspections (all activities prescribed in technical instructions). }\end{array}$ \\
\hline TRANSPORT & $\begin{array}{l}\text { Movement control and the use of communications in the zone of } \\
\text { operations; regulation and control of military traffic participants } \\
\text { (movement control for motorized military motorcades, and } \\
\text { sometimes for individual vehicles in public transport and the } \\
\text { regulation and control of the movement of military participants in } \\
\text { public transport and closed military areas). Application of security } \\
\text { measures in movement and transport.Personnel transport and cargo } \\
\text { transport. Obligations in equipping and use of equipment from the } \\
\text { functional competence. }\end{array}$ \\
\hline
\end{tabular}




\begin{tabular}{|c|c|c|}
\hline $\begin{array}{l}\text { NAME OF } \\
\text { LOGISTICS } \\
\text { FUNCTION }\end{array}$ & \multicolumn{2}{|c|}{$\begin{array}{c}\text { ELEMENTS OF LOGISTICS } \\
\text { PREVENTION }\end{array}$} \\
\hline HEALT CARE & \multicolumn{2}{|c|}{$\begin{array}{l}\text { Medical support (preventive medical care: hygiene and prophylactic } \\
\text { measures, anti-epidemic measures, medical measures for anti- } \\
\text { radiation, hemical, and biological protection; specific measures of } \\
\text { medical care and evaluation of sanitary-epidemiological situation. } \\
\text { Using equipment from the functional competence. } \\
\text { Veterinary support (veterinary - sanitary inspection of animals for } \\
\text { slaughter and foodstuff of animal origin, health care of ungulates, } \\
\text { isolation of wounded and sick ungulates). }\end{array}$} \\
\hline $\begin{array}{l}\text { GENERAL } \\
\text { LOGISTICS }\end{array}$ & \multicolumn{2}{|c|}{$\begin{array}{l}\text { Services to feed the personnel. Services for the purpose of dressing. } \\
\text { Communal services. Energy services. Furnishing facilities and } \\
\text { production and service plants. Accommodation and service activities } \\
\text { (accommodation of personnel, laundry and dry cleaning equipment, } \\
\text { bathing and dressing, barber, tailoring and shoemaking services, } \\
\text { payment services for the provision of energy products and electricity, } \\
\text { maintenance and production of general logistics equipment). } \\
\text { Service standards of general logistics services. Other general } \\
\text { logistics needs. Elements of the quality of life. }\end{array}$} \\
\hline INFRASTRUCTURE & \multicolumn{2}{|c|}{$\begin{array}{l}\text { Planning spatial development and alignment with the needs of } \\
\text { defense system. Management of real estate and rights related to } \\
\text { real estate. Current and investment (capital) maintenance. } \\
\text { Preventive and corrective maintenance of thermal power plants. }\end{array}$} \\
\hline \multirow{3}{*}{\multicolumn{3}{|c|}{$\begin{array}{l}\text { Logistics prevention involves two groups of tasks: } \\
\text { - tasks of preparing logistics prevention; } \\
\text { - tasks of implementing logistics prevention. } \\
\text { The phases of logistics prevention organisation and common tasks } \\
\text { realised within the frame of logistics functions are shown in Table } 3 \text {. } \\
\text { Table } 3 \text { - Logistics prevention phases and tasks } \\
\text { Таблица } 3 \text { - Этапы и задания логистической профрилактики } \\
\text { Табела } 3 \text { - Фазе и задаци логистичке превентиве }\end{array}$}} \\
\hline & & \\
\hline & & \\
\hline \multicolumn{3}{|c|}{ TASKS OF LOGISTICS PREVENTION } \\
\hline \multicolumn{2}{|c|}{$\begin{array}{l}\text { PHASES OF PREPARING LOGISTICS } \\
\text { PREVENTION }\end{array}$} & $\begin{array}{l}\text { PHASES OF IMPLEMENTING } \\
\text { LOGISTICS PREVENTION }\end{array}$ \\
\hline \multicolumn{2}{|c|}{$\begin{array}{l}\text { Quality design and dimensioning of logistics } \\
\text { systems dealing with logistics prevention, its } \\
\text { elements and processes. }\end{array}$} & $\begin{array}{l}\text { Practical application of specific } \\
\text { measures and actions of logistics } \\
\text { prevention. }\end{array}$ \\
\hline \multicolumn{2}{|c|}{$\begin{array}{l}\text { Identifying threats to logistics prevention and } \\
\text { chances that can facilitate the realization of } \\
\text { logistics prevention. }\end{array}$} & $\begin{array}{l}\text { Coordination of measures and } \\
\text { activities of logistics prevention to } \\
\text { give coordinated action and } \\
\text { homogeneous treatment at the } \\
\text { internal and external level. }\end{array}$ \\
\hline
\end{tabular}




\begin{tabular}{|c|c|}
\hline \multicolumn{2}{|c|}{ TASKS OF LOGISTICS PREVENTION } \\
\hline $\begin{array}{l}\text { PHASES OF PREPARING LOGISTICS } \\
\text { PREVENTION }\end{array}$ & $\begin{array}{l}\text { PHASES OF IMPLEMENTING } \\
\text { LOGISTICS PREVENTION }\end{array}$ \\
\hline $\begin{array}{l}\text { Identification and assessment of the needs } \\
\text { for logistics prevention and quantification of } \\
\text { logistics possibilities. }\end{array}$ & $\begin{array}{l}\text { Control over the quality and quantity } \\
\text { of applications of logistics prevention. }\end{array}$ \\
\hline $\begin{array}{l}\text { Planning logistics prevention (planning tasks, } \\
\text { manpower, material support, financial } \\
\text { support, if needed, intelligence and security } \\
\text { support) in all elements of logistics systems, } \\
\text { stages in the life cycle of the Army and } \\
\text { hierarchical levels of organisation of the } \\
\text { Army, taking into account all aspects of the } \\
\text { logistics prevention (spatial, time, } \\
\text { organisational and technological aspect). }\end{array}$ & $\begin{array}{l}\text { Application of the prescribed } \\
\text { measures and activities (individual } \\
\text { and collective) in accordance with the } \\
\text { prescribed time and exploitation } \\
\text { resources, principles, standards and } \\
\text { technology. }\end{array}$ \\
\hline $\begin{array}{l}\text { Education of logistics personnel in the field of } \\
\text { logistics prevention. }\end{array}$ & $\begin{array}{l}\text { Monitoring the key performance } \\
\text { indicators of logistics prevention and } \\
\text { measuring business parameters to } \\
\text { determine business performance. }\end{array}$ \\
\hline $\begin{array}{l}\text { Education of management personnel in the } \\
\text { field of logistics prevention. }\end{array}$ & $\begin{array}{l}\text { Practical application of acquired } \\
\text { knowledge by improving the state of } \\
\text { logistics prevention within one's } \\
\text { functional jurisdiction. }\end{array}$ \\
\hline $\begin{array}{l}\text { Education of nonlogistics personnel in the } \\
\text { field of logistics prevention and promotion of } \\
\text { preventive culture. }\end{array}$ & $\begin{array}{l}\text { Pactical application of acquired } \\
\text { knowledge by improving the state of } \\
\text { logistics prevention within one's } \\
\text { functional jurisdiction. }\end{array}$ \\
\hline $\begin{array}{l}\text { Consideration of control measures in logistics } \\
\text { prevention. }\end{array}$ & $\begin{array}{l}\text { Control of realization of } \\
\text { implementation of logistics prevention } \\
\text { measures. }\end{array}$ \\
\hline $\begin{array}{l}\text { Identifying the requirements of compatibility } \\
\text { in the field of logistics prevention. }\end{array}$ & $\begin{array}{l}\text { Control of compliance with the } \\
\text { applicable regulations of logistics } \\
\text { prevention. }\end{array}$ \\
\hline $\begin{array}{l}\text { The study of legal acts, regulations and } \\
\text { standards relating to the organisation and } \\
\text { technology of logistics prevention. }\end{array}$ & $\begin{array}{l}\text { Proposing amendments to logistics } \\
\text { prevention regulations. }\end{array}$ \\
\hline $\begin{array}{l}\text { Training subordinates in the application of } \\
\text { prescribed measures and activities (individual } \\
\text { and collective) in accordance with the } \\
\text { prescribed time and exploitation resources } \\
\text { and other principles and standards. }\end{array}$ & $\begin{array}{l}\text { Monitoring experiences and trends in } \\
\text { the field of prevention in other } \\
\text { organisations. }\end{array}$ \\
\hline $\begin{array}{l}\text { Monitoring the key performance indicators of } \\
\text { logistics prevention and measuring business } \\
\text { parameters to measure logistics prevention } \\
\text { success. }\end{array}$ & $\begin{array}{l}\text { Revisiting the representativeness of } \\
\text { the key performance indicators of } \\
\text { logistics prevention and methods for } \\
\text { their measurement. }\end{array}$ \\
\hline $\begin{array}{l}\text { Preparation and implementation } \\
\text { onsidered regarding the levels of the }\end{array}$ & $\begin{array}{l}\text { f logistics prevention should } \\
\text { defence system organisation ar }\end{array}$ \\
\hline
\end{tabular}


structure (especially the Army as its most important part) and regarding the logistics system organisation and structure. In that process, all phases of the defence system life cycle and their respective tasks should be covered. A simplified model of a logistics prevention organisation in the defence system is shown in Table 4.

Tabel 4 - Model of logistics prevention organisation

Таблииа 4 - Модель логистической профьлактики

Табела 4 - Модел организовања логистичке превентиве

\begin{tabular}{|c|c|c|c|c|c|c|}
\hline \multirow{3}{*}{$\begin{array}{l}\text { NAME OF } \\
\text { LOGISTICS } \\
\text { FUNCTIONS AND } \\
\text { THEIR STRUCTURE } \\
\text { BY THE LEVELS OF } \\
\text { THE DEFENCE } \\
\text { SYSTEM } \\
\text { ORGANISATION }\end{array}$} & \multicolumn{6}{|c|}{$\begin{array}{l}\text { PHASES IN THE ARMY LIFE CYCLE WHERE THE ARMY } \\
\text { PERFORMS ITS TASKS, DELIVERS RESULTS AND } \\
\text { ACHIEVES GOALS }\end{array}$} \\
\hline & \multicolumn{2}{|c|}{$\begin{array}{l}\text { PEACE (including } \\
\text { crisis and } \\
\text { emergency } \\
\text { situations) }\end{array}$} & \multicolumn{2}{|c|}{ MOBILIZATION } & \multicolumn{2}{|l|}{ WAR } \\
\hline & $\begin{array}{l}\text { prep. } \\
\text { of log. } \\
\text { prev. }\end{array}$ & $\begin{array}{l}\text { implem. } \\
\text { of log. } \\
\text { prev. }\end{array}$ & $\begin{array}{l}\text { prep. } \\
\text { of log. } \\
\text { prev. }\end{array}$ & $\begin{array}{l}\text { implem. } \\
\text { of log. } \\
\text { prev. }\end{array}$ & $\begin{array}{l}\text { prep. } \\
\text { of log. } \\
\text { prev. }\end{array}$ & $\begin{array}{l}\text { implem. } \\
\text { of log. } \\
\text { prev. }\end{array}$ \\
\hline $\begin{array}{l}\text { SUPPLY } \\
\text {.. subfunctions } \\
\text {..elements of the } \\
\text { system which realizes } \\
\text { the function... }\end{array}$ & \multirow{6}{*}{\multicolumn{6}{|c|}{$\begin{array}{l}\text { WHO?, WHAT?, WHERE?, WHEN?, WITH WHAT AND } \\
\text { WITH WHOM?, HOW AND HOW MUCH?, HOW MUCH IS } \\
\text { THAT?, CONSEQUENCES OF LOGISTICS PREVENTION } \\
\text { ABSENCE } \\
\text { (spatial, time, organisational and technological and financial } \\
\text { aspects) }\end{array}$}} \\
\hline $\begin{array}{l}\text { MAINTENANCE } \\
\text {.. subfunctions } \\
\text {..elements of the } \\
\text { system which realizes } \\
\text { the function... }\end{array}$ & & & & & & \\
\hline $\begin{array}{l}\text { TRANSPORT } \\
\text {.. subfunctions } \\
\text {..elements of the } \\
\text { system which realizes } \\
\text { the function... }\end{array}$ & & & & & & \\
\hline $\begin{array}{l}\text { HEALT CARE } \\
\text {.. subfunctions } \\
\text {..elements of the } \\
\text { system which realizes } \\
\text { the function... }\end{array}$ & & & & & & \\
\hline $\begin{array}{l}\text { GENERAL LOGISTIC } \\
\text { subfunctions } \\
\text {..elements of the } \\
\text { system which realizes } \\
\text { the function... }\end{array}$ & & & & & & \\
\hline $\begin{array}{l}\text { INFRACTURE } \\
\text {.. subfunctions } \\
\text {..elements of the } \\
\text { system which realizes } \\
\text { the function... }\end{array}$ & & & & & & \\
\hline
\end{tabular}




\section{Elements of the concept of logistics prevention development}

Necessary elements of the concept of logistics prevention development are logistics functions performance indicators and quantitive indicators of logistics needs and abilities (number of members, surface area, volumes, time resources, exploitation resources, work ability, capacities, overhaul ability, etc.).

Design of logistics processes and dimensioning their resources (personnel, equipment, object, facilities) must be carried out for the most unfavorable system condition (extreme load). The degree of filling for a specific state is regulated by management decisions. The system's ability to move fast from one state to another must be taken into account (from peace to the state of war) where implementing its own transformation and the transformation of the supported system must be carried out at the same time.

Based on the aforementioned (Project "VA -TT/6/13-15", 2015), it can be concluded that the approach to the development of logistics prevention must be holistic. The elements that must be considered in the concept of logistics prevention development are as follows:

- Managing personnel (addmision in the logistics system, staff training management, necessary knowledge, skills, habits, attitudes, training, education and specialisation, leaving the logistics system);

- Equipment and supplies from the logistics jurisdiction (defining the scope and quality needs and ways for their procurement);

- Equipment and supplies necessary for logistics unit activities (defining the scope and quality needs and ways of their procurement);

- Logistics infrastructure (facilities, plants, installations, etc.);

- Peacetime and wartime organisation schemes of logistics bodies and units;

- Peacetime and wartime individual and material formations of logistics bodies and units;

- Logistics bodies jurisdictions and tasks in accordance with the army organisation levels;

- Optimising the implementation of logistics processes and information, material and energy flows in defence logistics;

- Logistics norms, logistics military literature and documentation;

- Logistics defence planning and logistics support planning;

- The principles of the constitution and functioning of logistics; 
- Method of functioning of logistics bodies and units and the method of executing logistics tasks;

- Logistics support to logistics bodies and units;

- Logistics information system (Andrejić et al, 2010, pp.33-61);

- Degree of internal organisation within the logistics system and coordination of functioning of logistics bodies at different hierarchical levels;

- Degree of readiness (availability) and reliability of logistics services, bodies and units for the implementation of tasks in each of assigned missions;

- Army training for the preparation and execution of logistics operations;

- Resources required for the development of logistics services (by type, quantity and quality);

- Application of the concept of integrated logistics support in equipping the Army with armament and military equipment (Andrejić \& Sokolović, 2009, pp.32-53);

- Improving logistics aspects of training, education and specialisation of nonlogistics personnel;

- Modeling of logistics units for usual (standard) and "ad hoc" tasks;

- Modalities of the reliance of logistics in the Army on the state logistics;

- Logistics interoperability;

- Control parameters and evaluation of achieved status, performance and quality of work of logistics units;

- Focal points and priorities in the theoretical and operational functioning of the logistics system,

- Management of the development and operation of logistics.

The developing concept of logistics prevention requires active work, energetic and coordinated actions of all logistics subjects in the defence system.

Investment in personnel, organisational and tehnological modernization, equipment, plants and installations modernization and management, should not be regarded as a cost but as investment for better future for logistics services and the overall defence system.

The concept of logistics prevention development as an intelectual and philosophical idea must be followed by a detailed logistics prevention operation plan. It must get answers to the following questions: What?, Who?, How? Until when?, Where?, Who with?, How?, With what and how to realise it?, How much does it cost? and Who provides resources? 


\section{Conclusion}

The data reported in this paper, as a result of the observation of a real logistics support system, show that certain LoS functions have developed preventive actions and this characteristic makes them more effective in practice. In addition, there is still a lot of space for the existing state of the logistics prevention to become more perfect. Development and full implementation of the proposed concept of logistics prevention significantly contribute to the rationalization of many demands in appearance, optimising the structure and dimensioning of logistics elements, reducing the stress of the system, reducing costs and increasing efficiency and effectiveness. The overall quality of logistics prevention depends on the quality of the application at the place where logistics requirements appear, but also on the quality of the design of logistics prevention carried out at higher hierarchical levels of the logistics system organisation. The battle for a high level of readiness, availability and long life of the system (organisational, technical and biological) is won with high quality logistics prevention. Failures due to the imperfections of the logistics prevention system (poorly-designed) or due to insufficient quality functioning of logistics prevention generate significant negative consequences in the system in a form of unnecessarily high costs, failure to execute specific tasks or loss of life (Generalštab Vojske Srbije, 2009). During the design and implementation of organisational changes in defense logistics, all elements of the logistics system functions and processes should be viewed critically and in terms of benefits for the preparation and implementation of logistics prevention (Stanojević et al, 1999, p.651). One way of improving the quality of logistics prevention is timely recognition of user's requests and responses to them, based on an adequate information system and rapid transport (Andrejić \& Ljubojević, 2009, pp.15-27). While searching for an optimal model of logistics prevention, what should be taken into account is logistics interoperability (both at the national and international level), developed in accordance with the dynamics of integrations in the field of defense and our real possibilities.

\section{References}

Andrejić, M., \& Ljubojević, S., 2009. Operaciona istraživanja u funkciji podrške odlučivanju u sistemu odbrane. Vojnotehnički glasnik/Military Technical Courier, 57(3), pp.15-27 (in Serbian). Available at: http://dx.doi.org/10.5937/vojtehg0903015A.

Andrejić, M., Milenkov, M., \& Sokolović, V., 2010. Logistički informacioni sistem. Vojnotehnički glasnik/Military Technical Courier, 58(1), pp.33-61 (in Serbian). Available at: http://dx.doi.org/ 10.5937/vojtehg1001033A. 
Andrejić, M., \& Sokolović, V., 2009. Integralna logistička podrška sredstava naoružanja i vojne opreme. Vojnotehnički glasnik/Military Technical Courier, 57(1), pp.32-53 (in Serbian). Available at: http://dx.doi.org/10.5937/vojtehg0901032A.

Atanasković, P., Đorđević, D. \& Sajfert, D., 2012a. Analysis of requirements and the necessary investments in the railway station adjustment program for persons with special needs. Industrija, 40(1), pp.191-199.

Atanasković, P., Nikoličić, S. \& Cvijanović, S., 2012b. Analysis of required investment and benefits using RFID in supply chains. Industrija, 40(2), pp.69-78.

Atanasković, P., Sajfert, D. \& Cvijanović, S., 2009. Istraživanje uloge i zadataka rukovodioca projekta. Industrija, 37(2), pp.127-139 (in Serbian).

Pamučar, D., Vasin, Lj., Atanasković, P. \& Miličić, M., 2016. Planning the City Logistics Terminal Location by Applying the Green p-Median Model and Type-2 Neurofuzzy Network. Computational Intelligence and Neuroscience, ISSN: 1687-5265, Vol. 2016 (2016), ISBN 1687-5265 (online). Hindawi Publishing Corporation.

- Generalštab Vojske Srbije, 2009. Koncept razvoja službi logistike, studija. Naređenje načelnika Uprave za logistiku GŠ VS (J-4), int. broj 128-1, od 21.01.2009. godine (projekat u toku), Beograd, Generalštab Vojske Srbije Uprava za logistiku (in Serbian).

- Project "VA -TT/6/13-15", 2015. Model baze podataka za podršku odlučivanja organa logistike (in Serbian).

Stanojević, P., Mišković, V., Siladić, M., Ilić, S., Andrejić, M., Milićević, M., \& Spasojević, Z., 1999. Opis i analiza sistema održavanja u Vojsci Jugoslavije (studija), Primena logističkog pristupa u organizaciji Vojske Jugoslavije (projekat). Beograd: SP GŠ VJ, p.651 (in Serbian).

http://www.harco.rs/o-podmazivanju.htlm. Accessed: 20 August 2015.

http://autobusi.net. Accessed: 20 August 2015.

http://www.termografija.rs. Accessed: 20 August 2015.

http://studiob.rs. Accessed: 20 August 2015.

\section{КОНЦЕПТ РАЗВИТИЯ ПРОФИЛАКТИЧЕСКИХ МЕРОПРИЯТИЙ В} ОБЛАСТИ ЛОГИСТИКИ В СИСТЕМЕ ОБОРОНЫ

Игорь Й. Эплер, Марко Д. Андреич, Марьян А. Миленков,

Влада С. Соколович

Университет обороны в г. Белград, Военная академия,

Кафедра логистики, г. Белград, Республика Сербия

ОБЛАСТЬ: логистика

ВИД СТАТЬИ: профессиональная статья

ЯЗЫК СТАТЬИ: английский 
Резюме:

Проорилактические мероприятия в области логистики необходимо рассматривать как систему (включающую подсистемы u элементы), как фрункцию (группа однородных заданий, организованных по определенному критерию) и как процесс (порядок действий в течение определенного времени). Профрилактические мероприятия являются неотъемлемой частью логистической поддержки в системе обороны, они способствуют предотвращению возможности нарушения запроектированных функций и деятельности системы и ее элементов (а также объектов деятельности), следовательно, они оказывают большое влияние на развитие функций системы в целом. Профрилактические мероприятия как функция включают комплекс мероприятий, разработанных $и$ организованных подразделениями Логистики. $A$ в осуществлении данных мероприятий принимают участие как логистический персонал, так и сотрудники других подразделений. Цель данных мероприятий заключается в предупреждении явлений и процессов, которые могли бы неблагоприятно повлиять на функции системы обороны. Во время осуществления маситабных организационных перемен системы обороны роль профилактических мероприятий в области логистики особенно важна, поэтому их системной разработке необходимо посвятить особое внимание. В разработке профилактических мероприятий в области логистики применяются те же принципы и подход, как и в проектировании, подготовке и осуществлении логистической обороны в целом.

Ключевые слова: военная логистика, система, профилактические мероприятия.

КОНЦЕПТ РАЗВОЈА ЛОГИСТИЧКЕ ПРЕВЕНТИВЕ У СИСТЕМУ ОДБРАНЕ

Игор Ј. Еплер, Марко Д. Андрејић, Марјан А. Миленков, Влада С. Соколовић

Универзитет одбране у Београду, Војна академија, Катедра логистике, Београд, Република Србија

ОБЛАСТ: логистика

ВРСТА ЧЛАНКА: стручни чланак

ЈЕЗИК ЧЛАНКА: енгЛескИ

\section{Сажетак:}

Логистичку превентиву треба посматрати као систем (сачињен од подсистема и елемената), као фуункцију (група сродних задатака груписаних по одређеном критеријуму) и као процес (ток 
уређених догађаја у времену). Логистичка превентива је део укупне логистичке подршке систему одбране који спречава да се наруше пројектоване, у ствари постојеће перформансе система који се подржава и његових елемената (објеката деловања логистике), односно који утиче на унапређење перформанси система који подржава. Логистичка превентива, као фрункција, подразумева све мере и активности које планирају и организују логистички органи, а реализују логистички органи, јединице и нелогистичко особље. Оне су усмерене на спречавање наступања појава и процеса који негативно делују на способности и перформансе система одбране. У времену интензивних организационих промена $у$ систему одбране, системском уређењу логистичке превентиве треба дати адекватан значај и посветити му нарочиту пажњу. Принципи који се односе на пројектовање, припрему и фуннкционисање логистике одбране у целини односе се и на пројектовање, припрему и спровођење логистичке превентиве.

Кључне речи: војна логистика, систем, логистичка превентива.

Paper received on / Дата получения работы / Датум пријема чланка: 23.08.2015.

Manuscript corrections submitted on / Дата получения исправленной версии работы / Датум достављања исправки рукописа: 29.05.2017.

Paper accepted for publishing on / Дата окончательного согласования работы / Датум коначног прихватања чланка за објављивање: 31.05.2017.

(C) 2017 The Authors. Published by Vojnotehnički glasnik / Military Technical Courier (www.vtg.mod.gov.rs, втг.мо.упр.срб). This article is an open access article distributed under the terms and conditions of the Creative Commons Attribution license (http://creativecommons.org/licenses/by/3.0/rs/).

() 2017 Авторы. Опубликовано в «Военно-технический вестник / Vojnotehnički glasnik / Military Technical Courier» (www.vtg.mod.gov.rs, втг.мо.упр.срб). Данная статья в открытом доступе и распространяется в соответствии с лицензией «Creative Commons» (http://creativecommons.org/licenses/by/3.0/rs/).

(๐) 2017 Аутори. Објавио Војнотехнички гласник / Vojnotehnički glasnik / Military Technical Courier (www.vtg.mod.gov.rs, втг.мо.упр.срб). Ово је чланак отвореног приступа и дистрибуира се у складу са Creative Commons licencom (http://creativecommons.org/licenses/by/3.0/rs/).

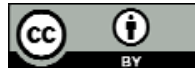

